\title{
The Concept of Self: Ramanuja
}

\section{Allaerts W* \\ Biological Publishing A\&O, The Netherlands}

*Corresponding author: Wilfried Allaerts, Biological Publishing A\&O, Nijverdal, The

Netherlands

\section{Research Article \\ Volume 2 Issue 4}

Received Date: November 11, 2019

Published Date: December 03, 2019

DOI: $10.23880 /$ phij-16000130

\section{Abstract}

The philosophical problem of the Inside - Outside duality has a long history. In this paper I recall that not only this duality caught the attention of philosophers like F. Nietzsche, G.W.F. Hegel and J.-P. Sartre, but it also formed the pièce de résistance in the famous controversy between S.A. Kierkegaard and Th.W. Adorno. In Nietzsche's early work Menschliches, allzumenschliches (1878), an interesting starting point is found that reminded me of the also famous, original viewpoint of M. Proust as expressed in À la Recherche du Temps Perdu (1914). Doing so, these re-collections brought me to a re-formulation of my 1992 paper on the problem of the linearity of written language and the nature of communication. This paper aims at showing that the translation of the Inside-Outside duality in a contemporary context together with a non-linear topography of natural communication, allows us to answer T. Morton's (2016) challenging logic of the hyper-real and so-called agrilogistics view on ecology. It is concluded that this debate is indeed important to distillate a logic of future coexistence.

\section{Prolegomenon}

When and where will be your next booking? We all know the tenacity of advertisement offers on the Internet. Then, when I finally enter a booked hotel room, I absorb the atmosphere of my new surroundings and start wondering. Two minutes after leaving the hotel room, or be it a motel or lodge, I am finding myself in the woods and sniffing in the moldy scent of moist humus. How comes this humid forest air always be filling me with a pleasant mood, whereas the putrefying smell of hotel bathroom mold, on the contrary, makes me nauseate? The piercing stench irritates my respiratory system or triggers the smooth muscle cells of my bronchial tubes. It makes them sneezing, gasping and puffing, or is this strong reaction caused by the caustic cleaning product that the housekeeper (or the maintenance team) has scattered around just before my arrival in order to unmask using corrosive chemicals the fungal foulness in this hotel bathroom?

The contrast can't be more trenchant, just as it is perceived by my olfactory senses, and, consequently, I am asking myself whether a scientifically sound answer could be given to these questions. Could we design an experiment in order to estimate the number of different odorous stimuli and their relation to one another and the different gradations of recognition by my alated nasal sense organ? Moreover, could we measure the physiological response to these stimuli, both for the mildly savoring forest ground and for the harsh bathroom smell? Where to take the proper measurements, in my brains or directly in the airway epithelia of nose or bronchial tubes? Methodological doubts arise as soon as 
we try to set up an empirical investigation, but the philosophical estrangements already loom up at the confrontation with the available vocabulary ${ }^{1}$ : how many words for 'smell' or for 'odorous sensations' exist in the English, Dutch or German languages? Which language has to be preferred? And do we have a topographical reference frame for the chemical fragrances or for the physiological reactions they evoke, in order to identify, classify and measure these phenomena?

The philosophical astonishment described above recalls some of the early pages of Friedrich Nietzsche's work Menschliches, allzumenschliches (1878)2 ${ }^{2}$ In $\mathbb{1 0}$ of this work, entitled 'Harmlosigkeit der Metaphysik in der Zukunft', Nietzsche starts to discard the world of Religion, Art and Ethics from the being of the World an sich, but the 'openness' of the being of the World (den erschlossenen Wesen der Welt) ${ }^{3}$ so far hasn't included my olfactory experiencing of the physical world. I must admit that I am not ready to leave all my questions in the hands of the physiologists or the developmental biologists, as Nietzsche seemed to suggest ${ }^{3}$. For I am not quite confident that the scientists involved in the study of the development of organs and organisms, and our understanding in the mechanisms of developmental and evolutionary biology, have solved all these questions that are in one way or another related to the riddle of the biological self ${ }^{4}$. If my olfactory senses, eventually including some kind of pheromone signaling, indeed are involved in mate choice and contact preferences ${ }^{5}$, the biological self-non-self-recognition not only hinges upon a (subconscious) olfactory signaling system, similar to the immune system 6 ; moreover, the biological self plays an integrative role in our contact with the so-called 'openness' of the World an sich. Intuitively, this relationship can be regarded as severely problematic in the view of nineteenth century philosophical traditions ${ }^{4,6}$. The most interesting point, and the main reason why we

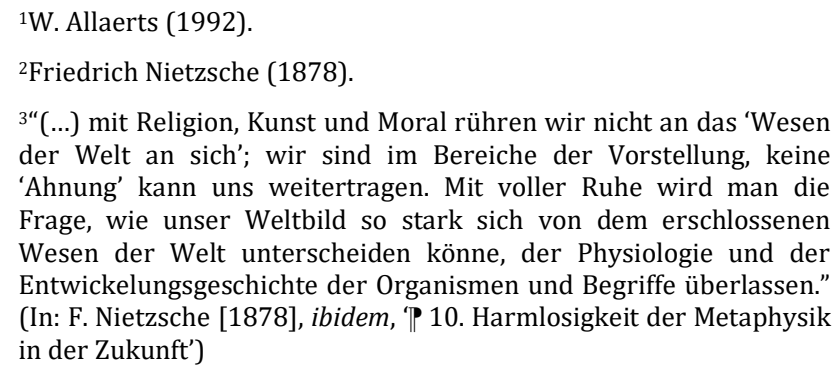
der Welt an sich'; wir sind im Bereiche der Vorstellung, keine 'Ahnung' kann uns weitertragen. Mit voller Ruhe wird man die Frage, wie unser Weltbild so stark sich von dem erschlossenen Wesen der Welt unterscheiden könne, der Physiologie und der Entwickelungsgeschichte der Organismen und Begriffe überlassen." (In: F. Nietzsche [1878], ibidem, ' $\mathbb{1}$ 10. Harmlosigkeit der Metaphysik in der Zukunft')

${ }^{4}$ W Allaerts (1997).

5 J Hurst (2018); MJ Baum (2012).

${ }^{6}$ W Allaerts (1999). opened this prolegomenon with a quote from Nietzsche's work, is found in the following paragraphs of the same work, namely in $\mathbb{P} 15$, entitled 'Kein Innen und Aussen in der Welt' ${ }^{7}$. It is not the aim of this paper to elaborate on Nietzsche's discussion of metaphysics and religion. We previously elaborated on the annihilation of the insideoutside dualism in the work of J.-P. Sartre and the importance of this dualism in the biological functionalist approach of the self ${ }^{4}$. Of course, also the famous refutation of S.A. Kierkegaard's notion of 'Die Innerlichkeit' in Th.W. Adorno's Nachschrift of his habilitation thesis ${ }^{8}$ is linked to this philosophical controversy, which dates back to the ancient notion of the 'For intérieur'(Consciousness): in Voltaire's Dictionnaire philosophique (1764) the 'For intérieur' had to be discarded from the 'exterior' realms of religion and state politics ${ }^{9}$. Rather than to re-enter the philosophical cul-de-sac of religion and consciousness, we will elaborate on the implications of the inside-outside dualism for an integrative approach of a world sensibility that matches with contemporary knowledge of the physical world.

\section{The Inside-Outside Duality Nietzsche and Hegel to Sartre)}

Not only the early Nietzsche, but also the work of G.W.F. Hegel is important in order to understand how the ancient notion of 'For intérieur' - that was still in use in Voltaire's epoche (see $\mathbb{P} 1$ ) - became the object of a fierce refutation, as proposed by Nietzsche $^{2}$ and also, although much later, by J.-P. Sartre ${ }^{10}$. The influence of Hegel cannot be over-estimated, although, we could hardly call Nietzsche a devote Hegelian to start with!11 Sartre, on the

\footnotetext{
7"Wie Demokrit die Begriffe Oben und Unten auf den unendlichen Raum übertrug, wo sie keinen Sinn haben, so die Philosophen überhaupt den Begriff 'Innen und Aussen' auf Wesen und Erscheinung der Welt; sie meinen, mit tiefen Gefühlen komme man tief in's Innere, nahe man sich dem Herzen der Natur. Aber diese Gefühle sind nur insofern tief, als mit ihnen, kaum bemerkbar, gewisse complicirte Gedankengruppen regelmässig erregt werden, welche wir tief nennen; ein Gefühl ist tief, weil wir den begleitenden Gedanken für tief halten, Aber der tiefe Gedanke kann dennoch der Wahrheit sehr fern sein, wie zum Beispiel jeder metaphysische; (...)" (In: F. Nietzsche [1878], ibidem, ' $\mathbb{P} 15$. Kein Innen und Aussen in der Welt')

${ }^{8}$ ThW Adorno (1962).

${ }^{9}$ D Lochak (1994).

${ }^{10}$ JP Sartre (1943).

${ }^{11}$ Although the work of F. Nietzsche definitely forms a class of itself, in his correspondence a far greater influence of the work of Arthur Schopenhauer (1788-1860) can be found than that of G.W.F. Hegel (1770-1831). Around 1820 at the Berlin University, Schopenhauer and Hegel are embroiled with each other because of the 'deep'
} 
other hand, even calls Hegel a 'genius', where Hegel surpassed the Husserlian phenomenological position (about the liaison between the Self and the World) ${ }^{12}$. This is shown in the passage where Sartre explains Hegel's idea of the double, reciprocal relation of mutual exclusion of the consciousness of the Other, as worked out in the Phänomenologie des Geistes ${ }^{13}$.

In Chapter IV of this Phänomenologie, Hegel expands the idea of the double nature of the Self-consciousness, being both independent and dependent on the Selfconsciousness of the Other. This results in two opposite Gestalts of the (Self) conscience, one is der Herr (das Fürsichsein, the Independent), the other is der Knecht ("das unselbständige, dem das Leben oder das Sein für ein Anderes das Wesen ist") ${ }^{14}$. These concepts of Herr and Knecht in Hegel, however, are related to the ontology of Self-consciousness of the individual, and are not to be confused with the Übermensch construct (and the contrasting 'slave' notion) as for instance developed in Nietzsche's Also sprach Zarathustra ${ }^{15}$. In contrast to Nietzsche and also Sartre, Hegel does adhere to the distinction of Gestalts of the Inner and Outer Being: "Das Innere als solches muß ebensosehr ein äußeres Sein und eine Gestalt haben wie das Äußere als solches, den es ist Gegenstand oder selbst als Seiendes und für die Beobachtung vorhanden gesetzt" 16 . These notions are important for Hegel in order to explain the experience of 'sensibility' (Sensibilität, "etwa als Nervensystem"), of 'irritableness' (Irritabilität, "als Muskelsystem") and of 'reproduction' (Reproduktion), the latter for the indivual's physiological functioning and survival of the species ("Als Eingeweide der Erhaltung des Individuums und des Gattung") ${ }^{17}$. However, the 'organic Substance' of the 'Innere', also called the 'einfache Seele' by Hegel, should be understood as a teleonomic principle (Zweckbegriff) ${ }^{18}$. So, it remains what Hegel calls 'allgemeine Flussigkeit'. For

philosophical differences between their minds. (Source: Arthur Schopenhauer [1859])

12JP Sartre (1943), ibidem, p. 281.

${ }^{13}$ GWF Hegel (1832-1845).

${ }^{14}$ GWF Hegel (1832-1845), ibidem, p. 150.

${ }^{15} \mathrm{~F}$ Nietzsche (1885).

${ }^{16}$ GWF Hegel (1832-1845), ibidem, p. 203.

${ }^{17}$ GWF Hegel (1832-1845), ibidem, p. 204.

${ }^{18}$ For a critical definition of the often misunderstood notion of 'teleonomy', see the work of Jacques Monod (1970); see also our discussion of this teleonomy notion by J. Monod and contrasting contemporary viewpoints in certain schools of neo-darwinism, see e.g. in W. Allaerts (2007): 325-337.
Kierkegaard, Hegel here would have missed the point of criticizing the weakness of Kant's system ${ }^{19}$, which criticism of Hegel in turn will be rejected by Adorno, because, in the words of Adorno, Kierkegaard would have missed the correct interpretation of Hegel's notion of 'mediation' (Vermittlung) in the Phänomenologie des Geistes $^{20}$ (see also $\mathbb{2}$ ).

With Sartre (1943), however, the distinction of the being 'für Sichselbst', or the pour soi, and the being en soi (or Dasein an sich) has taken a giant leap away from Hegel's Gestalts of Inner and Outer Being (see above). It would be interesting to compare the Nietzschean route into the 'Will to Power' as an alternative, philosophical way out. In order to conclude the Kierkegaard-Adorno controversy, we found Paul Tillich's analysis of Nietzsche's 'Will to Power' very instructive ${ }^{21}$. Moreover, as Tillich pointed out, Kierkegaard broke away from Hegel's "classical system of essentialism"22 and therefore

\begin{abstract}
${ }^{19 " J e}$ mehr im Kritizismus das Ich in die Beschauung das Ich versank, desto magere rund magerer wurde dieses Ich, bis es schließlich ein Gespenst wurde, unsterblich wie Auroras Gatte. Es ging dem Ich wie dem Raben, der, von dem Lobreden des Fuchses über seine Person entzückt, den Knochen verlor. Indem die Reflexion beständig über die Reflexion reflektierte, war das Denken auf einen Abweg gekommen und jeder Schritt, den es vorwärts tat, führte es natürlich weier und weiter von allem Inhalt fort. (...) Es ging die Philosophie wie einem Mann, der seine Brille auf hat und dennach nach seiner Brille sucht, er sucht nämlich dem, was ihm vor der Nase liegt, aber er sucht es nicht auf der Nase, und daher findet er es nie. Aber das für die Erfahrung Äußere, das wie ein harter Körper mit dem Erfahrenden zusammenstieß, warauf durch die Kraft des Zusammenstoßes jeder seinen Weg ging - das Ding an sich, das ständig dabei verharrte, das erfahrende Subjekt zu versuchen (so wie ein gewisse Schule im Mittelalter glaubte, die sichtbaren Zeichen im Abendmahle seien dazu da, um den Glauben zu versuchen) - dieses Äußere, dieses Ding an sich machte die Schwache von Kants System aus." Cited from: S申ren A. Kierkegaard (1841, 1929), p. 228.
\end{abstract}

${ }^{20} \mathrm{Th}$. W. Adorno (1962), p. 244; see also our discussion in: W. Allaerts (2017), p. 45-52.

${ }^{21}$ “One could say paradoxically that Nietzsche's will to power is neither will nor power, that is, is neither will in the psychological sense nor power in the sociological sense. It designates the selfaffirmation of life as life, including self-preservation and growth. Therefore the will does not strive for something it does not have, for some object outside itself, but wills itself in the double sense of preserving and transcending itself. Will to power is the selfaffirmation of the will as ultimate reality. (...) But in order to reach such a nobility (to surpass itself) it is necessary to obey and to command and to obey while commanding (...). In commanding itself it becomes its own judge and its own victim." Cited from: P. Tillich (1952), p. 26-27, 29.

${ }^{22}$ "When Kierkegaard broke away from Hegel's system of essences he did two things: he proclaimed an existential attitude and he instigated a philosophy of existence". Cited from: P. Tillich (1952), p. 116. 
should be regarded as an important link between the philosophies of Hegel and XX ${ }^{\text {th }}$ century Existentialism.

On the other hand, Hegel's philosophy has also put an enormous load on the $\mathrm{XX}^{\text {th }}$ century philosophical systems, leading into historical movements like 'tectonic plates floating on the Earth's mantle' (according to some) ${ }^{23}$. These remarks refer to the Hegelian readings by philosophers like Karl Marx (and also Slavoj Žižek), that would largely change the architectonic landscape of societies in the previous century. But, there's something

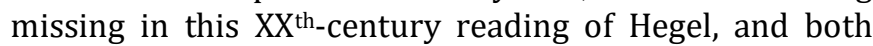
Nietzsche and Sartre made their contributions to our understanding of this missing link, something unpalpable our (biological) selves are confronted with: smell.

\section{Proust, the Linearity of Text and Missing Topography of Smell}

Following our introductory remarks in the Prolegomenon ( $\mathbb{P} 1)$, we come back to the importance of smell as a different sensory approach then visual or auditory recognition and the importance of this alternative sensitivity in historical and philosophical terms. Of course, there is a long tradition of works referring to the classical novel $\hat{A}$ la Recherche du Temps Perdu (1914) by Marcel Proust and in particular the episode where the taste of a typical biscuit, called madeleine, trenched in a cup of tea, alters the way the protagonist discovers his surrounding World 24 . One could say that, apart from making reference to a particular, Japanese entertainment play, the passage cited from

\footnotetext{
${ }^{23}$ A. Butterworth (2010).

24“Et dès que j'eus reconnu le goût du morceau de madeleine trempé dans le tilleul qui me donnait ma tante (quoique je ne susse pas encore et dusse remettre à bien plus tard de découvrir pourquoi ce souvenir me rendait si heureux), aussitôt la vieille maison grise sur la rue, où était sa chambre, vint comme un décor de théâtre s'appliquer au petit pavillon, donnant sur le jardin, qu'on avait construit pour mes parents sur ses derrières (ce pan tronqué que seul j'avais revu jusque-là); et avec la maison, la ville, depuis le matin jusqu'au soir et par tous les temps, la Place où on m'envoyait avant déjeuner, les rues où j'allais faire des courses, les chemins qu'on prenait si le temps était beau. Et comme dans ce jeu où les Japonais s'amusent à tremper dans un bol de porcelaine rempli d'eau, de petits morceaux de papier jusque-là indistincts qui, à peine y sont-ils plongés s'étirent, se contournent, se colorent, se différencient, deviennent des fleurs, des maisons, des personnages consistants et reconnaissables, de même maintenant toutes les fleurs de notre jardin et celles du parc de M. Swann, et les nymphéas de la Vivonne, et les bonnes gens du village et leurs petits logis et l'église et tout Combray et ses environs, tout cela qui prend forme et solidité, est sorti, ville et jardins, de ma tasse de thé." [Bold by WA] Cited from: Marcel Proust (Éd. 1914), p. 58.
}

Proust ${ }^{24}$ doesn't offer much information but elaborates in an enormously laborious way on the individual's experience of - indeed - a special moment. Also, one could argue that this style of writing is typical for the whole of Proust's novel, and maybe even for a generation of novelists (sometimes called the surrealist movement in literature). To our opinion, however, although this novel should indeed be regarded as a milestone in the history of literature, it still misses the dimension of opening another dimension of sensitivity beyond the language of describing it. For, the author wants or makes us to believe that the taste of a madeleine trenched in tea opens a whole new world, probably because it gives him a souvenir of a distant past, which gives him that special moment of happiness and that changes everything, but not for us. If we would want to experience a similar moment of happiness, if we would believe that such an approach works, it would only be possible through the act of having that experience, not through the language describing the process. And still, it would not offer us any comprehension of the topography of these smell or other senses, nor of the memories of events coupled in some way to these experiences in our brain. The question is not how to mimick this experiencing of a memory by stimulating the very precise spots in our brain, but the question is how our brains get triggered by multiple senses and how some of these complicated interactions between outside world and sensory input are related to a sheer feeling of happiness? If we would know, it would probably become very tempting to create a kind of Pavlovian stimulus-response trigger for creating a (constant or repetitive) feeling of happiness. On the other hand, we all know where this kind of happiness-deliveryon-demand methods have led into, when we look at the lost generations of youngsters, addicted to one or another hedonic mechanism (not only drugs, of course).

We still miss a proper understanding of the topography of smell, or we may miss a proper understanding of dealing with sensory experiences altogether. Biological investigation has pointed out that smell (and unknown or subconscious stimuli) are important in mammals for mate choice for reproduction (also in humans, presumably) 5 , and the more so even to rule out or avoid reproduction with individuals of close kin, and without being conscious of that selective mechanism $^{5}$. This is what natural selection does too, although, in the case of our own species, we are mostly not aware of the existence of these mechanisms and are tended to describe them in terms of cultural imprinting. 
In the past few millennia of cultural development, different ways of communicating through vocal signaling have evolved and also many cultures developed what in general terms can be described as 'music'. Some cultures (like Chinese, ancient Greek, medieval roman and some others) also developed a musical notation system, allowing for a conformal coding system for describing variations in pitch, duration, and all kinds of rhythmic and harmonic combinations of tunes. We previously discussed the analogy between music and non-linear information transmission ${ }^{1}$. In textual information (like written language, non-spoken), transmission in principal is linear ${ }^{25}$, unless one is not an actual person but a computer (robot) or some machine trained to read or respond to several textual messages at the same time (note the important concept of simultaneity in information transmission) ${ }^{1}$. However, in music and also in other signaling systems, there is no need for a complete identity between the different tonal lines (of information) arriving simultaneously. So, music is by its very nature a nonlinear form of information transmission, but, so far, it is also the only non-linear information transmission system, based on sensory input and output, for which a notation code or score system has been worked out during generations of human culture $\left({ }^{26}\right)$.

There is no such notation system for conveying odorous information (other than describing it in certain

\footnotetext{
${ }^{25}$ The linearity of textual information is a linearity by convention: letters in any alphabetic system are a two-dimensional pattern of dots and stripes (also recognized as 'symbols'), of which up- and downside have been determined as well as the order in which they have to be read in a text, from right to left as well as the opposite, top to bottom or the other way. The fact that linearity of written language has been postulated in almost any human culture, makes it more understandable that a predilection for linear coding systems comes to expression in nearly every aspect of human culture.

${ }^{26}$ In this respect, it is interesting to mention the ground-breaking work of Ernst Cassirer (1946), Language and Myth, where he explores 'the place of language and myth in the pattern of human culture'. In the first chapter of this work, Cassirer starts with the opening passage of the Platonic dialogue Phaedrus, describing Socrates' answer to Phaedrus on the Boreas and Orithyia myth. According to the philologist Max Müller, it is in the ambiguity of linguistic notation, the so-called 'paronymia' of words, that lies the source of all myths (referring e.g. to the assonant, almost similar words for stone $[\lambda \alpha \dot{\alpha} \alpha \varsigma]$ and men/warriors [ $\left[\lambda \alpha o^{\prime}\right]$ to denote the origin of the Deucalion and Pyrrha myth: they were ancestors of a new race - after the great flood destroyed mankind - and were created out of stones by the divine Zeus) (after M. Müller [1873], fide: Cassirer, 1946, 1953). So it is the deceptive similarity of words with different meanings that entails the tracks of tales, myth and language. But, according to Cassirer, not only the 'paronymia' of words but the very realization of symbolization, "which in fact is nothing but a sort of phantasmagoria of the spirit" is the essence of the "appearance of myth, art and language" (Cassirer, p. 7-8).
}

languages) ${ }^{27}$, but, sensory evolution has offered an enormous variety of odorous receptors, so that we can 'read' the chemistry of odorous signals - at least some of us can do the trick - but we cannot write them down. There is no alphabet, no exhaustive catalogue and there is also no conclusiveness on a 1-to-1 based relation between scents and perceived odors, nor a universality in the prevalence of receptors for a certain scent in any population. In other words, there is not only no conventional topography of smell, we simply don't know how odorous signaling works at the level of populations, ethnic or social groups, or at the level of humanity as a whole. But that also holds for several forms of sensory information transmission when regarding an increasingly huge proportion of the global population. For, that kind of sensory information appears to be at variance with the common practice of short text messaging or other digital tokens: a majority of modern humans simply isn't aware how sensory signaling works in its nature, neither it knows how to use its senses in Nature. Consequently, one could argue that either "we are lost", or "Nature has lost its impact upon us". But, there is no point in jumping into conclusions, let's first have a look of what other influential players have put up as an alternative.

Of interest in this context are also the reminders formulated by Marshall McLuhan ${ }^{28}$ in Understanding Media, stating that in $17^{\text {th }}$ century China and Japan, time was measured by odors, not only the hours and days, but also the seasons and even zodiac signs. In 1964, McLuhan also proposed the idea that the media were more important than the content they carried ${ }^{28}$. Therefore, he suggested that the characteristics of the medium were more important than the information content they conveyed, introducing a kind of philosophical-media way of thinking. In the next paragraphs, these ideas re-appear indicating their persistency in contemporary culture.

\section{The Re-discovery of Smell/Odor}

Today, I heard a child was denied access to the next school level, because of his bad smell. The teachers believed the boy, not a refugee and neither from any minority, couldn't properly perform in the next class with such a smell. Somewhere in the Netherlands, some child is refused, but the reason for the odorous mismatch is almost unanimously concealed as the primary reason for

\footnotetext{
${ }^{27}$ In this paper we won't discuss attempts of experimenters who tried to put chemicals in printed ink, so that when reading while touching the printed matter, chemicals would become released and give an odorous signal to the reader.

${ }^{28}$ M McLuhan (1964).
} 
exclusion, because such behavior in general is regarded socially unacceptable. We aren't very keen to admit or even feel embarrassed to mention the conspicuous importance of odorous recognition in choosing our fellows. Almost at the same time, the beagle dog Cliff at the Amsterdam University Hospital achieves what DNAmicroarray technology fails to accomplish. The dog points at the patients infected with Clostridium difficile bacteria and so helps the clinical staff at selecting the patients for proper medical treatment of $\mathrm{CD}$ associated diarrhea ${ }^{29}$. The struggling discoveries of the DNA-double helix replication and DNA-RNA transcription mechanisms were not persevered in the 1950'ies for this reason, neither the Human Genome sequencing project (HUGO) in the 1990'ies wasn't set up - nor gargantuan financing programs edified - to come to this end: that a dog can smell what we can't measure! Although we are capable of measuring a lot of scarcely present and tiny substances, the dog's nose unveils something we cannot diagnose with our instruments. Similar to our feelings regarding the exclusion of a child at school, we feel embarrassed to admit that odorous communication so badly harmonizes with our common sense of scientific progress. Moreover, biomedical scientific literature isn't very helpful in explaining why we are unable to do something, because more and more it became tradition to boast about successes and keep silent about what is not achieved or maybe remains unachievable in the future.

Meanwhile, in our zoological garden, brown bears in heat have no problem in sending scent messages and in this way they communicate with their sexual partners about their age, physical strength and mating preferences. Without much ado or without philosophical considerations, the bear's brain and olfactory system seize both the contours and the content of their partners portfolio. We may well benefit from that knowledge in our zoo reproduction programs, there is nothing strange about that, isn't it? However, according to some (see e.g. Timothy Morton, 2016) ${ }^{30}$, these observations point to the strangeness or uncanniness of the space (world) we live in. Why, is it strange to become a part of the man-made environment, called the Anthropocene, a place described as a "place (which) is a twist you can't iron out of the fabric of things"? 30 . Morton explained this uncanniness of the local (world) in his book Hyperobjects ${ }^{31}$. According to Morton, "place has a strange loop form because place

\footnotetext{
${ }^{29} \mathrm{C}$ Kraaijvanger (2012).

${ }^{30} \mathrm{~T}$ Morton (2016).

${ }^{31} \mathrm{~T}$ Morton (2013).
}

deeply involves time" and objects in space become "hyperobjects, (in order) to remind us that the local is in fact the uncanny" 30 . Within this respect, it is tempting to recall my previous work on the spatio-temporal contingency of cellular communication systems ${ }^{1}$, but this work was definitely devoted to the realm of cells and cellular communication systems and not to the realm of human interactions or inter-subjectivity ${ }^{1}$. But, when trying to extrapolate the uncanniness of the local (microscopic) world to the big world of hyper-objects, and to the world in itself as a kind of meta-hyperobject, we think Morton indeed has made a point.

Why then, is it not enough to state that the strangeness of a natural or animal world isn't as strange as some believers of the hyper-real do think? In the next paragraph, we will see that not only there is a strange loop in space (as Morton argues) ${ }^{30}$, but that Morton's argumentation also shows a strange loop, bringing us back to Hegel and his theory of mediation (Vermittlung) (see $\mathbb{P} 2$ and below).

\section{Timothy Morton: a Strange Loop Indeed}

It is important, right from the start, to get rid of the misconception that the so-called strangeness of space reflects some holistic versus reductionist view on physics. Morton explains that the simplified view of holism as "the whole is greater than the sum of its parts depends on some (false) concept of smooth, homogenous universality of space or infinity. It depends, in short, on a Euclidean anthropocentric geometry"32. For, hyper-objects reveal just the opposite, Morton explains, "the whole is always weirdly less than the sum of its parts". Morton gives the example of megacities, which are hard to conceptualize for architects and urban planners: the reason why we can't point to megacities "is deeply because we've been looking in the wrong place for wholes"31. It is due to the "awareness of the global (as in global warning), that we know that a megacity is a place among places". This is indeed a far more interesting starting point than the holism-reductionism controversy, namely the starting point that something may be wrong in our anthropogenic world, exemplified by the observation of (the effects of) global warming. But how are 'more' and 'less' defined in Morton's logic of the hyper-real?

Take for instance the non-contradiction paradox of the 'meadow that isn't a meadow'. (The paradox is explained as follows: each time one blade of grass is removed, the

${ }^{32}$ T Morton (2016), p. 12. 


\section{Philosophy International Journal}

meadow still remains a meadow, referring to the Zeno paradoxes of the ancient Greek. But when one continues removing blades of grass, until finally a "huge patch of dirt or parking lot is what is left over"; or, on the contrary, when "a single blade of grass is planted on the bare patch of dirt", that doesn't make a meadow yet.) ${ }^{33}$. The definition of meadows in terms of biodiversity or biodiversity resilience, doesn't help us either, because all paradoxes, their formulation and contestation are phrased and limited within the formal rules of language, a set of letters ordered from top left to bottom right on a page or touch screen, with blanks and reading marks to define words, sentences, paragraphs. We cannot smell or observe them as bears or bees do.

In the philosophy of Timothy Morton, reality and also language no longer are what they are, but, in line with the philosophies of Slavoj Žižek (o 1949, Ljubljana) and Jacques Lacan (1901-1981), they are conceptualizations or symbolizations reflecting a topological loophole (as a Möbius strip or Klein bottle) 'becoming what they already were'34. Moreover, Morton refers to the work of Luce Irigaray ( o 1930), a Belgian feminist philosopher, and to the French Jacques Derrida (1930-2004) to exemplify this viewpoint by outing that "the language of women is not what it is". From a historical-philosophical perspective, these viewpoints in fact are indebted to Hegel's notion of 'Vermittlung' and also to the concept of 'Mechanical Memory'35. For Žižek, Hegel's analysis of 'Mechanical Memory' implicates the emptiness of subjective interiority: "the job of 'Mechanical Memory' is to flatten the ground of interiority to pure Being, to pure space... without opposition from a subjective interiority"35. Hegel explains the notion of mediation (Vermittlung) in the famous Vorrede to his Phänomenologie des Geistes. This explanation follows his exposition of 'das Ganze' as the completion of a process of 'becoming different', or, the process of 'becoming altogether': "Whether we speak about 'all animals' as the starting point for unfolding a zoology course, or about the 'divine Word' as a starting point for defining theology, we haven't accomplished anything yet but an initial, immediate contemplation of an absolute, general principle. The rest of the work is a process of 'becoming', and this is an abhorring

\footnotetext{
${ }^{33}$ T Morton (2016), p. 73-74.

${ }^{34}$ W Allaerts (2012).

${ }^{35}$ Žižek refers to the contrasts between the Hegelian and Derridean readings of Hegel's notion of 'Mechanical Memory' (see e.g. S. Žižek [1994], p. 46.)
}

(perhorreszierend) experience..."36. When it comes to the interpretation of Hegel's original notion of mediation (Vermittlung), we see different branches in the postmodern philosophical discourses, like these of Žižek and Morton (e.g. Morton's view of 'holism' [see above] and Hegel's notion of 'das Ganze' as 'das Allgemeine' ${ }^{36}$. However, the role of the subject's interiority, the soul so to speak, is generally worn out by language and by the omnipresent explicitations of the 'outer world', including these from our contemporaries ${ }^{37}$. The contemporary impact of social media on social life, only has amplified this preponderance of the virtual world of artificial 'media' on the real world of intersubjective communication $^{28}$. The impact of this transition is unwitnessed in our world's history.

Eons beyond the awakening of the hunter-gatherersettler transition, Morton introduces the 'three axioms of agrilogistics' with one important goal, namely "to make agrilogistic space speak and so to imagine how we can make programs that speak differently, that would form the substructure of a logic of future coexistence"38. The first axiom of 'agrilogistics', formulated as "(1) The Law of Noncontradiction is inviolable", is doubtful: "There is no good reason for it. We shall see that there are plenty of ways to violate this law, otherwise we wouldn't need a

${ }^{36}$ G.W.F. Hegel (1832-1845), ibidem, Vorrede, p. 24-25: “Das Wahre ist das Ganze. Das Ganze aber ist nur das durch seine Entwicklung sich vollendende Wesen. Es ist von dem Absoluten zu sagen, da $\beta$ es wesentlich Resultat, da $\beta$ es erst am Ende das ist, was es in Wahrheit ist; und hierin eben besteht seine Natur, Wirkliches, Subjekt oder Sichselbstwerden zu sein (...). Der Anfang, das Prinzip oder das Absolute, wie es zuerst und unmittelbar ausgesprochen wird, ist nur das Allgemeine. Sowenig wie ich sage: alle Tiere, dies Wort für eine Zoologie gelten kann, ebenso fällt es auf, da $\beta$ die Worte des Göttlichen, Absoluten, Ewigen usw. das nicht aussprechen, was darin enthalten ist; - und nur solche Worte drükken in der Tat die Anschauung als das Unmittelbare aus. Was mehr ist als ein solches Wort, der Übergang auch nur zu einem Satze, enthält ein Anderswerden, das zurückgenommen werden muß, ist ein Vermittlung. Diese aber ist das was perhorresziert wird, (...). Dies Perhorreszieren stammt aber in der Tat aus der Unbekanntschaft mit der Natur der Vermittlung und des absoluten Erkennens selbst. Denn die Vermittlung ist nicht anderes als die sich bewegende Sichselbstgleichheit, oder sie ist die Reflexion in sich selbst, das Moment des fürsichseienden Ich, die reine Negativität oder, auf ihre reine Abstraktion herabgesetzt, das einfache Werden. (...)"(bold by G.W.F. Hegel).

37This corresponds to what Cassirer (1946) calls the 'curse' of mediacy. Symbolism, and thus also language, is "bound to obscure what it seeks to reveal". All it may express, both of the 'inner' and the 'outer' world, is denotation, mere suggestion, an "empty shell to the totality of actual experience (...). That is true for the external as well as the inner world: When speaks the soul, alas, the soul no longer speaks!" (Cassirer, ibidem, p. 7).

${ }^{38}$ T Morton (2016), ibidem, p. 46. 


\section{Philosophy International Journal}

rule. This means that axiom (1) is a prescriptive statement disguised as a descriptive one. Formulated rightly, axiom (1) states, Thou shalt not violate the Law of Noncontradiction. Axiom (1) works by excluding (undomesticated) lifeforms that aren't part of your agrilogistic project..."39. We understand the provocative role of a cynical argument, but in this case, we may doubt that this formulation of 'agrilogistics' axioms may become helpful to think differently about future coexistence on the planet. To think about Dark Ecology, so-to-speak.

The phrase of "excluding undomesticated lifeforms that aren't part of your agrilogistic project", however, sheds some light on the "Law of Noncontradiction", namely that (certain) contradictions may be ruled out when the rules of logic are applied properly and scientific debates are not corrupted by political games or economic power. Take the example of the global biodiversity impairment: this global biodiversity impairment may seem in contrast with the still growing numbers of newly discovered invertebrate, bacterial and fungal species. This contrast, however, is the result of improper argumentation, simply because there still are more unknown, undetected species of microbial organisms (especially in the oceans and the largely unexplored soils of our planet $)^{40}$ than the numbers of microbial species that we know of their existence, or, that may disappear before we get the chance to encounter them, or that somewhere may have been described in scientific papers (that however may become obsolete with new data becoming rapidly available) ${ }^{41}$. But this huge mountain of ignorance may not prevent us from observing the unwitnessed proportions of disappearing, known and unknown species and habitats, by looking at the totality of man-made interventions on the planet. And, if we are unable to observe - or unwilling to witness what the Anthropocene has entailed - , we are still capable of measuring the indirect effects of a catastrophically induced biodiversity impairment, for instance when measuring the skewness of environmental antigen exposure in allergic patients ${ }^{41}$. But, speaking about arguments, adhering to the logistics of public speech, in all periods of history has been a matter of subjecting to the rules of power: subjecting to the limits of freedom of

\footnotetext{
${ }^{39}$ T Morton (2016), ibidem, p. 47.

${ }^{40} \mathrm{An}$ inestimable number of microbial organisms remains to be discovered and described. This is the more relevant to the $20 \%$ of the world oceans that still have been shielded from access for research or for other purposes (see Assubel, J.H., D.T. Crist and P.E. Waggoner [2010]).
}

${ }^{41}$ Allaerts W and Chang TW (2017). speech and currency and to the availability of public space, in order to share symbolizations of inner thoughts.

\section{Concluding remarks: Oblivia, the Internet, Rules of power and other Trivia}

Although philosophical considerations on the insideoutside dualism have some historical relevance, they are hardly useful for explaining e.g. the differences in clinical manifestation of patients with locked-in syndrome, adultage non-verbal autism or an advanced stage of Alzheimer's disease ${ }^{42}$. Neither will odorous sensations help for preserving social networks for the elderly, not even when dating websites would include olfactory profiling - who on earth would want a dating database 'swipe with odour' with veritable scent marks of the candidates? - , taking in mind that natural mate preference selection is evolved in the Eocene to rule out same-of-kin-selection ${ }^{5}$.

It is not only the habit of burning frankincenses as a token of respect for the foreign visitor that we welcome amidst us, that is lost in cultural transfer: the obliteration of human senses in our post-postmodern Internet-cloudy World has taken many leaps further. As a result of the Google Translate App, a tool that provides instant translation for users that are not familiar with a foreign language, the tool would make cumbersome language lessons redundant. That's precisely how globally the behavior of young generations evolves in response to modern cross-cultural contacts. "In the Shannon paradigm of communication - allowing the engineers to 'innovate' only on nodes that they can identify - thus not including social structures, other forms of intelligence.." Rob van Kranenburg ${ }^{43}$ wrote in a prosaic outlook of the world in the Internet of Things (IoT) era, also based on David Priestland's (2012) Merchant, Soldier, Sage. A New History of Power. Not only the linearization of language and communication, the very fabric of interaction between men and machines (including robots) becomes reduced to the technical characteristics of the nodes of the network. In some philosophical way, this argument echoes the viewpoint on 'hot and cool media' in McLuhan's Understanding Media ${ }^{28}$. Interestingly, David Levy (London) in a TV-interview (2015) expressed the idea of creating human-like robots with "senses for smell and diffusing odoriferous scents (...) and also endowed with emotions and haptic feeling potentials".

\footnotetext{
${ }^{42}$ Jones HR, Srinivasan J, Allam G and Baker R(2011).

${ }^{43}$ Kranenburg, R. van (2016).
} 
According to Priestland's adage ${ }^{43}$, the powers of military, scientific or religious leaders would all become reduced to trivial discursive mechanisms. However, recent political upheaval in a few Anglo-American Superpowers (and in others) has shown that these 'old' powers still dominate the political debate, albeit that ultra-modern communication technologies have replaced the old, rather trusted ones. Not very surprisingly, the Internet has also introduced a new disruptive mechanism, namely the discrimination between 'fake' news and 'truth', between facts and alternative facts (in the words of some of these new leaders) ${ }^{44}$.

But the biodiversity and climate debate cannot be pursued without a proper methodology and hard observational corroboration with the reported facts. With growing age, it is assumed that an individual's impact on its environment and surroundings diminishes. The obliteration of the individual's self-control and narratives, however are not the only threat in a world dominated by searching engines, intrusive analytica, 24/7 observation and ubiquitous IoT. Also the privacy is progressively eroded by replacing an anonymous forgetfulness in the Oblivion in Time (OiT), by an all-retrievable exposure in the megacities of data-storage companies (Google Inc. and alike), built with approval of the local governments, but without real consent - i.e. without a real possibility to refrain from participation - of the suppliers of the data.

Within the perspective of this socio-political developments, the inside-outside discourse may have found a new raison d'être, not as a ground for the being of the conscious self, but as a starting point for awareness of the climate-responsible individual.

\section{References}

1. Adorno Th W (1962) 'Kierkegaard noch einmal. (Dem Andenken Paul Tillichs)'. In: 'Kierkegaard: Konstruktion des Ästhetischen' (Herausgegeben von Rolf Tiedemann, unter mitwerkung von Gretel Adorno, Susan Buck-Morss und Klaus Schulz, Suhrkamp Verlag, 1962). Frankfurt am Main: Suhrkamp Taschenbuch Wissenschaft 1702.

2. Allaerts W (1992) Inquiry into the spatio-temporal contingency of cellular communication systems. Communication \& Cognition 25 (4): 277-294.

\footnotetext{
${ }^{44}$ Neiman S (2017).
}

Allaerts W. Into the Origins of the Inside - Outside Debate: Rediscovering Smell/Odor and Tracking the Steps of Nietzsche, Proust and Timothy Morton. Philos Int J 2019, 2(4): 000130.
3. Allaerts W (1997) The self and its biological function: contrasts between Popper and Sartre. Logique et Analyse 40(158): 189-214.

4. Allaerts W (1999) The biological function paradigm applied to the immunological self-non-self discrimination: critique of Tauber's phenomenological analysis. Journal for General Philosophy of Science 30: 155-171.

5. Allaerts W (2007) De Epistemologische Paradox van de Evolutie. Autonomie, Teleonomie en het denken over Intelligent Design. Streven 74(4): 325-337.

6. Allaerts W (2012) 'Slavoj Žižek, obscene interpreter between Hegel and Occupy movement. Enjoyment and view on women and causality'. bi-logical jg 4(1): 37-46.

7. Allaerts W (2017) When Teddy met Paulus (Tillich). Adorno on Kierkegaard again, 'das Ganze und die Innerlichkeit’. bi-logical, jg. 6(2): 45-52.

8. Allaerts W, Chang TW (2017) Skewed Exposure to Environmental Antigens Complements Hygiene Hypothesis in Explaining the Rise of Allergy. Acta Biotheoretica 65(2): 117-134.

9. Assubel JH, Crist DT, Waggoner PE (2010) First census of marine life 2010: highlights of a decade of discovery. A publication of the census of marine life, consortium of ocean leadership, Washington DC. Source.

10. Baum MJ (2012) Contribution of pheromones processed by the main olfactory system to mate recognition in female mammals. Frontiers in Neuroanatomy 6(20): 1-10.

11. Butterworth A (2010) The World that Never Was. A True Story of Dreamers, Schemers, Anarchists and Secret Agents. (Dutch Transl. I. Mertens; Uitgeverij Atheneum-Polak \& Van Gennep, Amsterdam, 2011).

12. Cassirer E (1946, 1953 Dover Ed.) 'Language and Myth. New York: Dover Publications Inc.

13. Hegel GWF (1832-1845) 'Phänomenologie des Geistes'. (Auf der Grundlage der Werke von 1832-1845 neu edierte Ausgabe Redaktion Eva Moldenhauer und Karl Markus Michel). Frankfurt am main: Suhrkamp Verlag, 1970 (Suhrkamp Taschenbuch Wissenschaft 603). 
14. Hurst J (2018) Communicating through scents: an interview with Jane Hurst. BMC Biology 16: 126.

15. Jones HR, Srinivasan J, Allam G, Baker R (2011) 'Netter's Neurology'. 2nd (Edn.), London, New York: Elsevier Saunders.

16. Kierkegaard SA $(1841,1929)$ 'Über den Begriff der Ironie mit ständiger Rücksicht auf Sokrates'. German Transl. from Danish by Schaeder $\mathrm{HH}$, München/Berlin, 1929 fide: Theodor W Adorno [1933], 'Kierkegaard: Konstruktion des Ästhetischen'. Herausgegeben von Rolf Tiedemann, u.m.v. Gretel Adorno, Susan Buck-Morss und Klaus Schulz, Suhrkamp Verlag, 1962).

17. Kraaijvanger (2012) 'Beagle Cliff kan zeer besmettelijke ziekenhuisbacterie opsporen'. Bron.

18. Kranenburg $R$ van (2016) 'This is a tactical withdrawal'. bi-logical jg 6(1): 12-16.

19. Lochak D (1994) 'For Intérieur et Liberté de Conscience'.

20. McLuhan M (1964) Understanding Media. The Extensions of Man. New York: McGraw-Hill.

21. Monod J (1970) Le Hasard et la Nécessité. Essai sur la philosophie naturelle de la biologie moderne. Paris: Éditions du seuil.

22. Morton T (2013) Hyperobjects: Philosophy and Ecology After the End of the World. Minneapolis: University of Minnesota Press.

23. Morton T (2016) Dark Ecology. For a Logic of Future Coexistence. New York, Chichester: Columbia University Press.

24. Müller M (1873) The Philosophy of Mythology, appended to 'Introduction to the Science of Religion'.
London, 1873 (fide Cassirer, [1946, 1953 Ed.] 'Language and Myth').

25. Neiman S (2017) Resistance and Reason in Post-truth Times'. Ecowin by Benevento Publishing / Lemniscaat b.v., Rotterdam.

26. Nietzsche F (1878) Menschliches, Allzumenschliches. Ein Buch für freie Geister, Dem Andenken Voltaire's geweiht zür Gedächtnissfeier seines Todestages, des 30 Mai 1778. Goethe Schiller Archiv, GSA 71/14,1 [D10].

27. Nietzsche F (1885) Also sprach Zarathustra. Ein Buch für Alle und Keinen, 'Prologue' pp: 14-15, 'On the 3 evils' pp: 194 (From: Kritische Studienausgabe, hg. Giorgio Colli and Mazzino Montinari [Berlin/New York 1967]. Dutch Transl. by R. van Hengel [2013] 'Zo sprak Zarathoestra. Een boek voor iedereen en niemand'. Utrecht/Antwerpen: Uitgeverij De Arbeiderspers).

28. Proust M (1914) Du Côté de chez Schwann. À la Recherche du Temps Perdu. Paris: Éd. Bernard Grasset, pp: 523.

29. Sartre JP (1943) L' Être et le Néant. Essai d'ontologie phénoménologique. Paris: Éditions Gallimard.

30. Schopenhauer A (1859) 'Die Welt als Wille und Vorstellung', HH Tillgner Verlag $3^{\text {rd }}$ (Edn.), Hamburg: Nikol Verlagsgesellschaft.

31. Tillich P (1952) 'The Courage to Be'. Binghamton, NY: Yale University Press, Vail-Ballou Press.

32. Žižek S (1994) Does the Subject Have a Cause?. In: Žižek S (Ed.), The Metastases of Enjoyment. On Women and Causality. Radical Thinkers Series, London, New York: Verso. 